Abstracta Iranica Abstranica

Revue bibliographique pour le domaine irano-aryen

Volume 32-33 | 2013

Comptes rendus des publications de 2009-2010

\title{
Bruno Jacobs, Michael C. A. Macdonald. Feldzeichnung eines Reiters aus der Umgebung von Tayma $\bar{a}^{\prime}$
}

\section{Astrid Nunn}

\section{(2) OpenEdition \\ 1 Journals}

\section{Édition électronique}

URL : http://journals.openedition.org/abstractairanica/40337

DOI : 10.4000/abstractairanica.40337

ISSN : 1961-960X

Éditeur :

CNRS (UMR 7528 Mondes iraniens et indiens), Éditions de l'IFRI

\section{Édition imprimée}

Date de publication : 1 décembre 2013

ISSN : 0240-8910

\section{Référence électronique}

Astrid Nunn, «Bruno Jacobs, Michael C. A. Macdonald. Feldzeichnung eines Reiters aus der Umgebung von Taymā'», Abstracta Iranica [En ligne], Volume 32-33 | 2013, document 81, mis en ligne le 01 juillet 2016, consulté le 27 septembre 2020. URL : http://journals.openedition.org/abstractairanica/40337 ; DOI : https://doi.org/10.4000/abstractairanica.40337

Ce document a été généré automatiquement le 27 septembre 2020.

Tous droits réservés 


\title{
Bruno Jacobs, Michael C. A. Macdonald. Feldzeichnung eines Reiters aus der Umgebung von Taymä'
}

\author{
Astrid Nunn
}

\section{RÉFÉRENCE}

Bruno Jacobs, Michael C. A. Macdonald. « Feldzeichnung eines Reiters aus der

Umgebung von Taymā' ». ZOrA 2, 2009, p. 364-376.

1 Le nouveau périodique Zeitschrift für Orient-Archäologie (vol. 1 paru en 2008) prend la suite des Baghdader Mitteilungen et des Damaszener Mitteilungen et est, après la restructuration du Deutsches Archäologisches Institut de Berlin, l'organe de la nouvelle "Orient-Abteilung" qui englobe le Proche-Orient jusqu'à l'Iran. Parmi les travaux dans cette région comptent les nouvelles fouilles à Teyma en Arabie-Séoudite, ville dans laquelle s'était réfugié le roi néo-babylonien Nabonide, qui avait refusé de rester à Babylone pour des raisons surtout religieuses. Les fouilles sont accompagnées de prospections, lors desquelles a été repéré, à $37 \mathrm{~km}$ de Tayma et sans lien apparent avec le site, le relief rupestre traité dans cet article. Il représente un cavalier, haut de $79 \mathrm{~cm}$, assis sur un cheval bondissant. Le cavalier porte une calotte, une barbe et un pantalon ainsi qu'un carquois à arc et flèches (gorytos). Ce relief pourrait stylistiquement être néo-assyrien ou néo-babylonien. Tout en sachant que ces deux périodes ont influencé l'art achéménide et que la période néobabylonienne est la plus probable, les AA. ne veulent néanmoins pas exclure le début de l'époque achéménide, lorsque cette région faisait partie de la satrapie Arabaya. 


\section{AUTEURS}

\section{ASTRID NUNN}

Université de Munich 